\title{
Sex-specific regulation of weight and puberty by the Lin28/let-7 axis
}

\author{
Christina Corre', Gen Shinoda ${ }^{2}$, Hao Zhu ${ }^{3}$, Diana L Cousminer, ${ }^{1,4}$, Christine Crossman ${ }^{1}$ \\ Christian Bellissimo', Anna Goldenberg ${ }^{5,6}$, George Q Daley ${ }^{2}$ and Mark R Palmert ${ }^{1,7}$ \\ 1 Division of Endocrinology, The Hospital for Sick Children, 555 University Avenue, Toronto ON, M5G 1X8, Canada \\ ${ }^{2}$ Division of Hematology/Oncology, Boston Children's Hospital, Boston, Massachusetts, USA \\ ${ }^{3}$ Departments of Pediatrics and Internal Medicine, Children's Research Institute, University of Texas Southwestern \\ Medical Center, Dallas, Texas, USA \\ ${ }^{4}$ Institute for Molecular Medicine, Finland (FIMM), University of Helsinki, Helsinki, Finland \\ ${ }^{5}$ Genetics and Genome Biology Program, The Hospital for Sick Children, Toronto, Ontario, Canada \\ ${ }^{6}$ Department of Computer Science, University of Toronto, Toronto, Ontario, Canada \\ ${ }^{7}$ Departments of Paediatrics and Physiology, The University of Toronto, Toronto, Ontario, Canada
}

\author{
Correspondence \\ should be addressed \\ to M R Palmert \\ Email \\ mark.palmert@sickkids.ca
}

\begin{abstract}
Growth and pubertal timing differ in boys and girls. Variants in/near LIN28B associate with age at menarche (AAM) in genome-wide association studies and some AAM-related variants associate with growth in a sex-specific manner. Sex-specific growth patterns in response to Lin28b perturbation have been detected in mice, and overexpression of Lin28a has been shown to alter pubertal timing in female mice. To investigate further how Lin28a and Lin28b affect growth and puberty in both males and females, we evaluated Lin28b loss-of-function (LOF) mice and Lin28a gain-of-function (GOF) mice. Because both Lin28a and Lin28b can act via the conserved microRNA let-7, we also examined let-7 GOF mice. As reported previously, Lin28b LOF led to lighter body weights only in male mice while Lin28a GOF yielded heavier mice of both sexes. Let-7 GOF mice weighed less than controls, and males were more affected than females. Timing of puberty was assessed by vaginal opening (VO) and preputial separation (PS). Male Lin28b LOF and male let-7 GOF, but not female, mice displayed alteration of pubertal timing, with later PS than controls. In contrast, both male and female Lin28a GOF mice displayed late onset of puberty. Together, these data point toward a complex system of regulation by Lin28a, Lin28b, and let-7, in which Lin28b and let-7 can impact both puberty and growth in a sex-specific manner, raising the possibility that this pathway may contribute to differential regulation of male and female growth and puberty in humans.
\end{abstract}

\section{Key Words \\ - puberty \\ - $\operatorname{Lin} 28$ \\ - let-7 \\ - sex-specific}

\section{Introduction}

Women tend to be shorter than men, and girls have their growth spurt at an earlier phase in puberty than boys (Styne \& Grumbach 2012). Girls also experience puberty at younger ages than boys and are more likely to exhibit precocious puberty, while boys are more likely to have delayed puberty (Carel \& Leger 2008, Walvoord 2010,
Palmert \& Dunkel 2012, Styne \& Grumbach 2012). The factors that contribute to these differences are unknown but important because variations in the timing of puberty have been associated with higher risk for adult metabolic abnormalities, cancer, and osteoporosis (Weir et al. 1998, Golub et al. 2008, Lakshman et al. 2009,

Published by Bioscientifica Ltd. 
Joinson et al. 2011, Seselj et al. 2012, Widen et al. 2012, Ritte et al. 2013, Day et al. 2015).

Growth and the timing of puberty are highly heritable, and genome wide association studies (GWAS) have identified many loci that modulate both traits. Interestingly, variants in/near LIN28B affect both adult height and the age at menarche (AAM; Lettre et al. 2008, He et al. 2009, Ong et al. 2009, Perry et al. 2009, Sulem et al. 2009, Elks et al. 2010, Widen et al. 2010, Leinonen et al. 2012, Cousminer et al. 2013, Perry et al. 2014), and two of the puberty-related single nucleotide polymorphism (SNPs) associate with growth and/or adult BMI in a sexspecific manner (Lettre et al. 2008, Widen et al. 2010, Ong et al. 2011, Leinonen et al. 2012). That this axis regulates these traits in a sex-specific manner is further supported by the finding that male but not female Lin28b loss-offunction (LOF) transgenic mice are lighter than controls (Shinoda et al. 2013b).

LIN28B and its paralogue, LIN28A, function as pluripotency factors, and their dysregulation has been implicated in a number of cancers (Yu et al. 2007, Peng et al. 2010, King et al. 2011, Molenaar et al. 2012, Sakurai et al. 2012, Yuan et al. 2012). Both genes encode RNAbinding proteins that inhibit maturation of the evolutionarily conserved let-7 microRNA (miRNA) family of developmental regulators (Heo et al. 2008). The Lin28a/ Lin28b/let-7 pathway is known to regulate the timing of larval development in Caenorhabditis elegans, germ layer specification in Xenopus, stem cell maintenance, glucose metabolism, and linear growth (Pasquinelli et al. 2000, Reinhart et al. 2000, Thomson et al. 2006, Heo et al. 2008, Newman et al. 2008, Rybak et al. 2008, Viswanathan et al. 2008, Melton et al. 2010, Zhu et al. 2011, Faas et al. 2013, Shinoda et al. 2013b). In rodents, expression patterns of Lin28a, Lin28b, and let-7 in the hypothalamus-pituitarygonad (HPG) tissues have been described by us and others (Zhu et al. 2010, Gaytan et al. 2013, Grieco et al. 2013, Sangiao-Alvarellos et al. 2013, Sangiao-Alvarellos et al. 2015). All genes are expressed in the hypothalamus, pituitary, and gonad around the age of puberty: while Lin28b is expressed at a higher level than Lin28a in the hypothalamus and testes, the relationship is reversed in the ovary (Gaytan et al. 2013, Grieco et al. 2013). In the pituitary Lin28b is only slightly more expressed than Lin28a (Grieco et al. 2013). Lin28a and Lin28b can downregulate let-7, but the expression patterns of Lin28a and Lin $28 b$ compared with let-7 are not always completely reciprocal (Gaytan et al. 2013, Grieco et al. 2013, Sangiao-Alvarellos et al. 2013, 2015).

How this pathway regulates the timing of puberty is largely unknown. However, data from model systems indicate that the causative gene at the AAM-associated GWAS locus is indeed LIN28B. In C. elegans, lin28 LOF as well as let-7 gain-of-function (GOF) lead to precocious larval development (Ambros \& Horvitz 1984, Reinhart et al. 2000). Analogously, Lin28a GOF female mice display delayed puberty (Zhu et al. 2010). This sex-specific regulation of body size by LIN28B in humans and mice and the involvement of this pathway in the regulation of pubertal timing lead us to examine whether Lin28a and Lin28b also regulate puberty in a sex-specific manner and whether let-7 is mediating such effects. We first utilized Lin $28 b$ LOF, Lin28a GOF, and let-7 GOF mice to validate the effects of perturbation of Lin28a, Lin28b, and let-7 expression on body weight in male and female mice. We then extended our analysis to include investigation of the roles of Lin28a, Lin28b, and let-7 in the timing of pubertal onset in male and female mice. Our results suggest that the regulation of these traits by Lin $28 a$ and Lin $28 b$ may differ and that some effects of Lin28b and let-7 are sex-specific.

\section{Materials and methods}

\section{Animals}

Studies were approved by the Toronto Centre for Phenogenomics (TCP) Animal Care Committee (AUP 09-08-0097) in accordance with recommendations of the Canadian Council on Animal Care, the requirements under Animals for Research Act, RSO 1980, and the TCP Committee Policies and Guidelines. Mice were maintained under controlled conditions $\left(25^{\circ} \mathrm{C}\right.$ and $10 \mathrm{~h}$ light: $14 \mathrm{~h}$ darkness cycle) in sterile, individually ventilated cages, provided irradiated chow and sterile water, and allowed to feed ad libitum via an automated watering system.

In Lin28b LOF ( $\operatorname{Lin} 28 b^{-/-}$) mice, exon 2 of $\operatorname{Lin} 28 b$ has been excised by targeted mutagenesis resulting in global absence of the Lin28b protein (Shinoda et al. 2013b). In the let-7 GOF strain, a M2-rtTA element has been inserted in the Rosa26 locus and a tetracycline-responsive element, followed by a transgenic let- $7 g$ sequence, has been inserted in the Col1A1 locus (Zhu et al. 2011, Shinoda et al. 2013b), leading to global upregulation of let- $7 \mathrm{~g}$ expression after administration of doxycycline (Beard et al. 2006). Normally, Lin28b binds to the stem loop of the let-7 pre-miRNA and prevents its processing to mature let-7 miRNA (Heo et al. 2008). To prevent such downregulation, the transgenic let-7 element has been engineered so that it cannot be bound by Lin28a or Lin28b (Zhu et al. 2011). Both strains have been used previously, and alterations in

Published by Bioscientifica Ltd. 
expression of $\operatorname{Lin} 28 \mathrm{~b}$ and let-7g have been validated ( $\mathrm{Zhu}$ et al. 2011, Shinoda et al. 2013b). In the Lin28a GOF mice, a tetracycline-responsive element, followed by a transgenic Lin28a sequence, has been inserted in the Col1A1 locus. This transgene is 'leaky' and leads to global upregulation of Lin28a even in the absence of the M2-rtTA element and doxyclycline administation ( $\mathrm{Zhu}$ et al. 2010). The Lin28b LOF and let-7 GOF strains were created in the Daley laboratory and maintained on a mixed background of C57BL6/J, 129, and Balb/C; Lin28a GOF mice were maintained on a C57BL6/J background (Zhu et al. 2011, Shinoda et al. 2013b). For our studies, male mice were imported and mated with superovulated C57BL6/J females for strain rederivation at the TCP Transgenic Core. Embryos were transferred to an inhouse C57BL6/J female and offspring were bred to each other to maintain the mixed genetic background. Prior to phenotyping the mice in our facility, LOF was confirmed by the absence of Lin $28 \mathrm{~b}$ protein in Lin $28 \mathrm{~b}$ LOF mice in the adult testes and let-7 GOF was confirmed by upregulated let- $7 \mathrm{~g}$ levels in livers of doxycycline-fed let-7 GOF mice. Successful rederivation of the Lin28a GOF mice was verified by recapitulation of the previously observed enlarged body sizes of Lin28a GOF mice.

Mice were fed a standard chow (Harlan, Teklad Global 18\% Protein Rodent Diet, 2018, Madison, WI) or the equivalent diet containing $625 \mathrm{mg} / \mathrm{kg}$ doxycycline (Harlan, TD.01306). For let-7 GOF experiments, mice were fed the doxycycline chow from birth, which induced transgenic let- $7 g$ expression in mice carrying the transgene, but not in littermate controls, by feeding the doxycycline chow to the lactating mother (beginning on the date of birth of her litter) and directly to the pups after weaning. Feeding doxycycline to lactating mothers is known to cause upregulation of doxycycline-inducible transgenes in pups (Sun et al. 2012). The Lin28a transgene is known to be leaky with increased expression that is sufficient to delay puberty in females and increase body weights in both males and females without administration of doxycycline (Zhu et al. 2010); thus, these mice were fed standard chow.

In every experiment mice were mated for one week, after which the male was removed. Females were transferred to an individual cage prior to giving birth. Date of birth was monitored daily between $0009 \mathrm{~h}$ and noon, and weaning was performed on postnatal day 21 with males and females then housed separately with a target of 3-4 weaned pups per cage. Littermate controls were used for all experiments. Phenotyping was done without knowledge of genotype, between $0009 \mathrm{~h}$ and noon every day. The timing of puberty was assessed by monitoring vaginal opening (VO) (Danilovich et al. 1999, Seminara et al. 2003, Krewson et al. 2004, FernandezFernandez et al. 2006, Sanchez-Garrido et al. 2013) and preputial separation (PS) (Korenbrot et al. 1977, Nathan et al. 2006, Takashima-Sasaki et al. 2006, Deboer \& Li 2011, Smith \& Spencer 2012, Sanchez-Garrido et al. 2013, Novaira et al. 2014) every day post-weaning. VO and PS are estradiol- and testosterone-dependent processes respectively, and altered day of VO correlates with other measures of pubertal timing (Chehab et al. 1997, Divall et al. 2010, Zhu et al. 2010, Caron et al. 2012, Dicken et al. 2012, True et al. 2015). Body weights were measured to $0.1 \mathrm{~g}$. Experiments were performed a minimum of two times to ensure that results were reproducible. Mouse genotypes from tail biopsies were determined using realtime PCR with specific probes designed for each gene (Transnetyx, Cordova, TN, USA).

\section{Tissue dissection}

Tissues were harvested following decapitation under isoflurane anesthesia. For hypothalamic tissue, whole brains were dissected and flash frozen in liquid nitrogen. The hypothalamus was then microdissected while frozen, according to established coordinates and landmarks (Baker et al. 1983, Grieco et al. 2013, Sangiao-Alvarellos et al. 2013). All other tissues were kept in RNAlater (Ambion, AM7021, Foster City, CA), at $-20^{\circ} \mathrm{C}$ until RNA extraction.

\section{Gene expression}

Tissues were homogenized in QIAsol solution (Qiagen, 1023537, Hilden, Germany) with a sonicator using a microtip, and RNA was extracted using the miRNeasy kit (Qiagen, 217004). DNAse treatment was performed during the RNA extraction using RNAse free DNAse (Qiagen, 79254).

RT-reactions were performed using the Taqman microRNA reverse transcription kit (ABI, 4366596, Foster City, CA) with specific RT-primers (ABI, 442795, assay id 377,2282 , and 1231, for let-7a, let-7g, and sno142 (housekeeping gene for normalization) respectively). Twenty nanogram total RNA was used in each RT reaction. As a standard, ovarian RNA from several 20-day-old C57BL6/J females was pooled and used in every experiment. Following reverse transcription $60 \mu \mathrm{l}$ of $10 \mathrm{mM}$ Tris pH 8 was added to each $15 \mu \mathrm{l}$ sample reaction and $6.65 \mu \mathrm{l}$ of the diluted sample was added to each Q-PCR reaction. For all Q-PCRs, the PefeCta FastMix II (Quanta, 95120-012,

Published by Bioscientifica Ltd 
Gaithersburg, MD, USA) was used along with the specific TM-primer for the Taqman microRNA assay.

Q-PCR was performed on a MX3 Pro Q-PCR system from Stratagene. Thermal cycling was performed with an initial denaturation at $95^{\circ} \mathrm{C}$ for $10 \mathrm{~min}$ followed by 40 cycles of $95^{\circ} \mathrm{C}$ for $15 \mathrm{~s}$ and $60^{\circ} \mathrm{C}$ for $60 \mathrm{~s}$. Every reaction was run in duplicate. Quantification used the standard curve method.

\section{Dexa}

Lean mass (g) and fat mass (g) were measured following euthanasia using peripheral dual-energy X-ray absorptiometry (pDXA, PIXImusII, GE Lunar Corp., Madison, WI, USA) at the Clinical Phenotyping Core at The Toronto Centre for Phenogenomics.

\section{Intraperitoneal glucose tolerance tests}

Intraperitoneal glucose tolerance tests (IP-GTT) were performed after a 6-h fast. A baseline blood sample was obtained from the tail vein and glucose was measured with an Ascencia glucometer (Bayer). A 10\% glucose solution (Sigma, G8644) was injected IP at a dose of $1 \mathrm{~g}$ glucose per kg bodyweight. Glucose was remeasured at 30, 60, and $120 \mathrm{~min}$ after the injection.

\section{Statistical analysis}

Statistical analyses, except linear regressions, were performed using Graphpad (Prism, La Jolla, CA, USA). Although experimental and control groups displayed equal variances, puberty data were not invariably normally distributed; thus PS and VO data were analyzed with Mann-Whitney non-parametric t-tests. Body weights displayed normal distribution and were analyzed with the student's $t$-test. Body weights on postnatal day 80 were also analyzed with a two-way ANOVA to test for sex-specificity. Linear regression of weight and age at puberty data was done using glm package in R. The regression coefficients were estimated using the control data and the fit of the mutant data to the wild type regression was estimated with the Kolmogorov-Smirnov test. DEXA and GTT data displayed unequal variances between experimental and control groups, and therefore $t$-tests assuming unequal variances were employed. Gene expression data were analyzed using the student's $t$-test. Results are reported as mean \pm s.D., with statistical significance attributed to $P<0.05$.

\section{Results}

\section{Growth}

Assessing growth patterns is an important component of the assessment of pubertal timing; therefore we began our studies by re-phenotyping growth (Table 1) at our centre.

As demonstrated previously, both male and female mice globally overexpressing Lin28a weighed more than littermate controls (Fig. 1A and B) (Zhu et al. 2010), while global Lin28b LOF males, but not females, weighed significantly less than littermate controls from postnatal day 21 onward (Fig. 1C and D) (Shinoda et al. 2013b). The sex-specific effect on weight among adult Lin28b LOF mice (postnatal day 80 ) was statistically significant after assessment with two-way ANOVA $(P=0.04$ after Bonferroni correction).

To begin to examine whether Lin28a/Lin28b regulate growth phenotypes via let-7, we phenotyped the let- $7 \mathrm{~g}$ GOF mice (Zhu et al. 2011) in which global overexpression was induced by feeding doxycycline chow to the pups from birth. Doxycycline administration was accomplished initially via transfer to the pups through the mother's milk (Sun et al. 2012) and subsequently by feeding directly to the pups after weaning. We chose to not induce let-7 overexpression during embryogenesis because this could be detrimental, as seen in Lin28a LOF embryos that overexpress let-7 and subsequently die as neonatal pups (Shinoda et al. 2013b). Because Lin28a and Lin28b can inhibit processing of let-7 precursors into functional miRNA (Heo et al. 2008), let-7 GOF mice were expected to phenocopy the Lin28b LOF mice if the effects of the Lin28b LOF model were mediated by increases in let-7 miRNAs. Indeed, the let-7 GOF mice weighed less than littermate controls (Fig. 1E and F) and males were more affected than females. Again, the sex-specificity of genotype effect on body weight on postnatal day 80 was found to be significant ( $P=0.0002$ after Bonferroni correction). Although the Lin28b LOF and let-7 GOF mice were similar,

Table 1 Summary of strains and numbers of mice per sex used in each experiment

\begin{tabular}{|c|c|c|c|}
\hline Perturbation & $\begin{array}{l}\text { Genetic } \\
\text { background }\end{array}$ & Puberty & $\begin{array}{c}\text { Body } \\
\text { weights }\end{array}$ \\
\hline Lin28a GOF & C57BL6/J & $15-33$ & $12-33$ \\
\hline Lin28b LOF & $\begin{array}{c}\text { 129, Balb/C, } \\
\text { C57BL6/J }\end{array}$ & $12-29$ & $7-15$ \\
\hline let-7 GOF & $\begin{array}{c}\text { 129, Balb/C, } \\
\text { C57BL6/J }\end{array}$ & $12-24$ & $7-24$ \\
\hline
\end{tabular}

Published by Bioscientifica Ltd. 

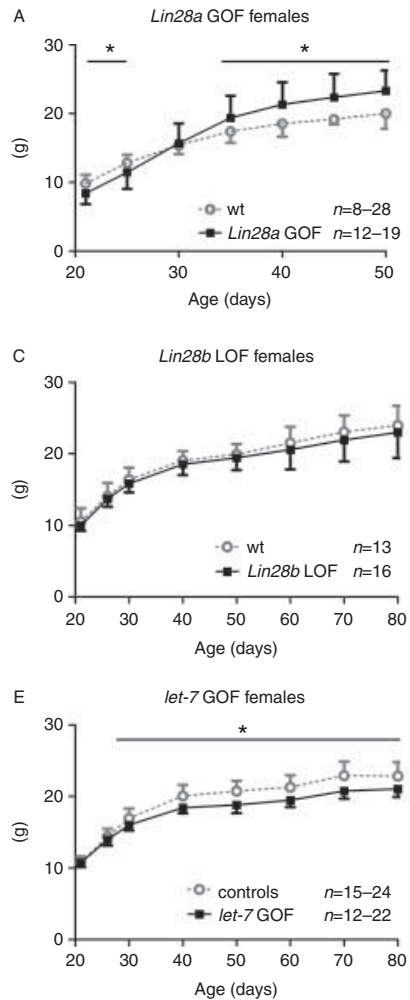
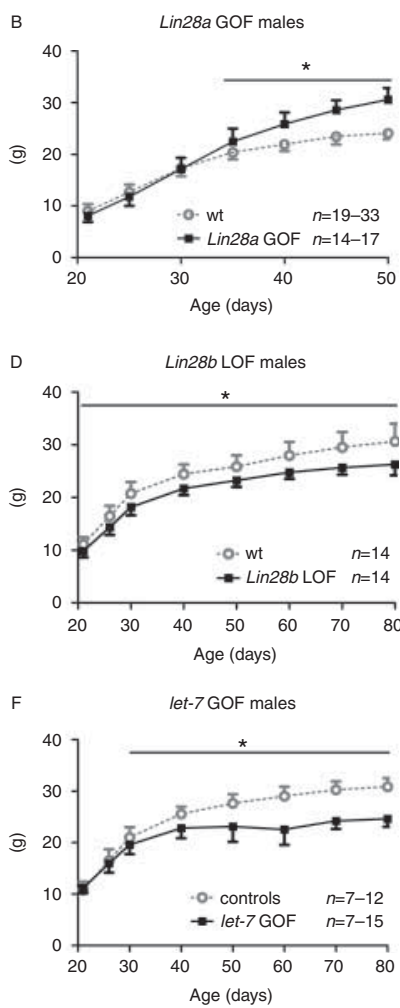

Figure 1

Growth patterns in Lin28a GOF (A and B), Lin28b LOF (C and D), and let-7 GOF (E and F) mice. The number of animals per group is indicated in each chart. Error bars represent S.D. Growth data were analyzed with the student's $t$-test at each time point. ${ }^{\star} P<0.05$.

differences were also apparent. For example, the lighter body weights in let-7 GOF males did not become apparent until postnatal day 30 , much later than the difference seen among the Lin $28 b$ LOF mice.

\section{Puberty}

Having confirmed sex-specific effects on growth, we next examined whether pubertal timing was regulated in a sex-specific manner in the three mouse strains. Pubertal timing in female mice was determined by daily assessments of $\mathrm{VO}$, and pubertal timing in male mice was determined by daily assessments of PS. It has previously been shown that Lin28a GOF females display delayed puberty, as measured by the day of $\mathrm{VO}$, age at first estrus and time of first pregnancy (Zhu et al. 2010). To determine whether Lin28a exerts this effect in a sex-specific manner, we phenotyped male and female mice in parallel. Both Lin28a GOF females and males exhibited delayed puberty $(P \leq 0.0001)$ (Fig. 2A and B) and were heavier at VO and PS than controls (Table 2).

Next we investigated pubertal timing in the Lin $28 b$ LOF mice. Female Lin28b LOF and WT littermates displayed $\mathrm{VO}$ at the same age (Fig. 2C). In contrast, the Lin28b LOF males displayed PS two days later than WT littermates $(P=0.004)$ (Fig. 2D). The let-7 GOF mice again phenocopied the Lin28b LOF mice: in let-7 GOF females, despite the lighter weight, VO occurred at the same age as in littermate controls (Fig. 2E) while let-7 GOF males reached PS later than controls $(P=0.004)$ (Fig. 2E and F). The delay in PS resulted in mice that were older and hence heavier at PS than controls (Table 2), suggesting that, at least in this strain, delayed growth could not explain the delayed puberty.

\section{Age/weight relationship at puberty}

Because the body weights at puberty were altered in different ways in the different strains the relationship between growth and age at puberty was examined further. A linear regression model was estimated for weight and age
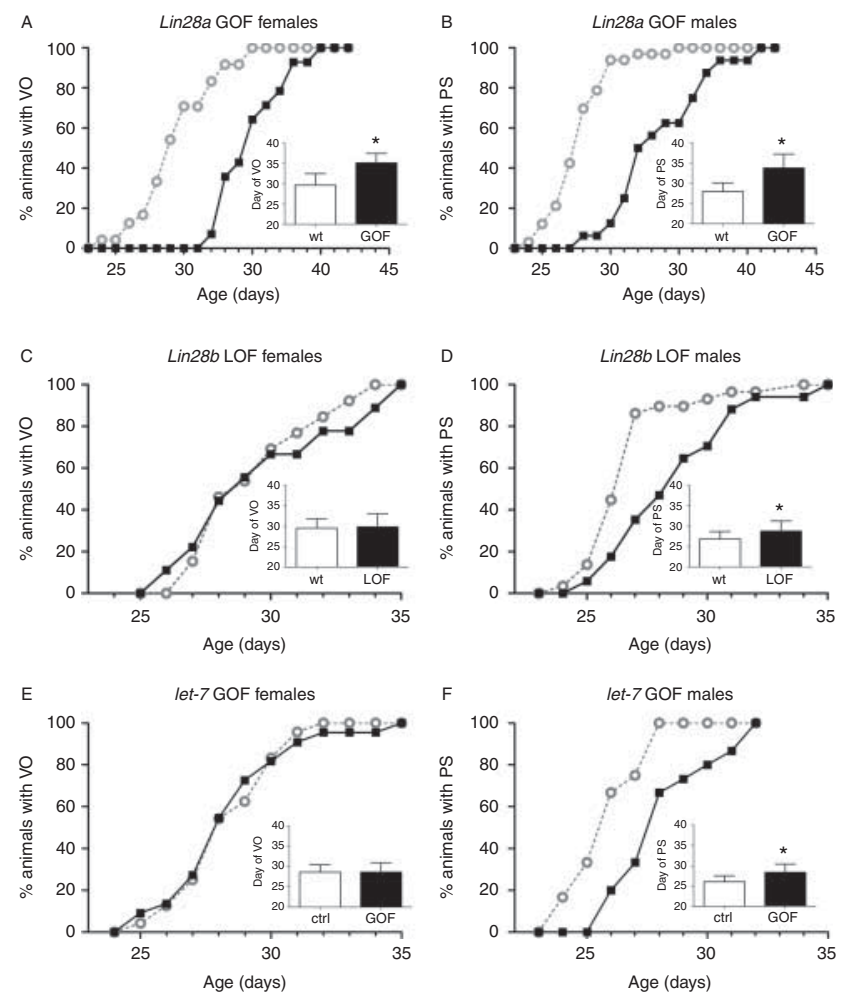

Figure 2

The onset of puberty, as assessed by VO and PS in Lin28a GOF, Lin28b LOF, and let-7 GOF mice. In each chart black boxes represent the GOF or LOF and open circles represent the control group. The inserted bar graphs display the mean day of VO or PS. Error bars represent S.D. $n=9-33$, exact numbers per group are indicated in Table 2. Puberty data were analyzed with the Mann-Whitney non-parametric $t$-test. ${ }^{*} P<0.05$.

Published by Bioscientifica Ltd 
Table 2 Comparison of pubertal body weight at puberty in Lin28a GOF, Lin28b LOF, and let-7 GOF male and female mice

\begin{tabular}{|c|c|c|c|}
\hline Genotype & Sex & $\begin{array}{c}\text { Weight at } \\
\text { VO/PS }\end{array}$ & $n$ \\
\hline $\mathrm{Wt}$ & $\mathrm{M}$ & $15.4 \pm 1.3$ & 33 \\
\hline Lin28a GOF & $\mathrm{M}$ & $\begin{array}{l}20.8 \pm 2.1 \\
P<0.0001\end{array}$ & 16 \\
\hline Wt & $\mathrm{F}$ & $15.3 \pm 1.5$ & 24 \\
\hline Lin28a GOF & $\mathrm{F}$ & $\begin{array}{l}21.1 \pm 2.0 \\
P<0.0001\end{array}$ & 15 \\
\hline $\mathrm{Wt}$ & $\mathrm{M}$ & $16.8 \pm 2.0$ & 29 \\
\hline Lin28b LOF & $\mathrm{M}$ & $\begin{array}{c}16.6 \pm 2.1 \\
\text { NS }\end{array}$ & 17 \\
\hline Wt & $\mathrm{F}$ & $15.5 \pm 0.8$ & 13 \\
\hline Lin28b LOF & $\mathrm{F}$ & $\begin{array}{c}14.8 \pm 1.3 \\
\text { NS }\end{array}$ & 9 \\
\hline Control & $M$ & $16.5 \pm 1.9$ & 12 \\
\hline let-7 GOF & $\mathrm{M}$ & $\begin{array}{c}18.2 \pm 2.1 \\
P=0.03\end{array}$ & 15 \\
\hline Control & $\mathrm{F}$ & $15.9 \pm 0.8$ & 24 \\
\hline let-7 GOF & $\mathrm{F}$ & $\begin{array}{l}15.3 \pm 1.0 \\
P=0.008\end{array}$ & 22 \\
\hline
\end{tabular}

$P$ values were calculated with the student's $t$-test.

at $\mathrm{VO} / \mathrm{PS}$ for the littermate controls, and then we examined whether the data from the LOF/GOF mice showed the same relationship (that is, did the data from the transgenic mice fit on the line for the control mice). For both female and male mice, the Lin28a GOF weight/age relationship was significantly different from the weight/age relationship observed among controls $\left(P=2.5 \times 10^{-5}\right.$ and $P=0.0015$ respectively, Fig. $3 \mathrm{~A}$ and $\left.\mathrm{B}\right)$, indicating that the alteration in Lin28a expression changed the relationship between growth and age of puberty in these mice. The relationship was changed similarly in female and male mice.

The Lin28b LOF females displayed body weights and VO similar to controls, and also exhibited a similar age/weight relationship at VO (Fig. 3C). The male Lin28b LOF mice displayed both slowed growth and delayed puberty, and the relationship between time of puberty and weight at PS was similar among the male Lin $28 b$ LOF mice and controls (Fig. 3D).

let-7 GOF females displayed a different age/weight relationship at VO compared with controls $\left(P=2.4 \times 10^{-5}\right)$ (Fig. 3E), perhaps indicating that the let-7 GOF affected growth but not age at VO. As for Lin28b LOF males, the age/weight relationship at PS was not different among male let-7 GOF mice and controls (Fig. 3F). These results provide further evidence that let-7 exerts its function differently in males and females.

\section{Body composition and glucose metabolism in young let-7 GOF mice}

Because let-7 GOF males weighed less than WT littermates, and because adult let-7 GOF mice have less body-fat than controls (Brill \& Moenter 2009, Frost \& Olson 2011, Zhu et al. 2011), we hypothesized that the delay in puberty could be due to a lower fat content in the male GOF mice. However, DEXA scans of pre-pubertal let-7 GOF mice showed no significant difference in body fat content or percent body fat compared with control littermates (Fig. 4A and B).

let-7 also affects glucose metabolism in adult mice and glucose metabolism could affect pubertal onset (Brill \& Moenter 2009, Frost \& Olson 2011, Zhu et al. 2011);
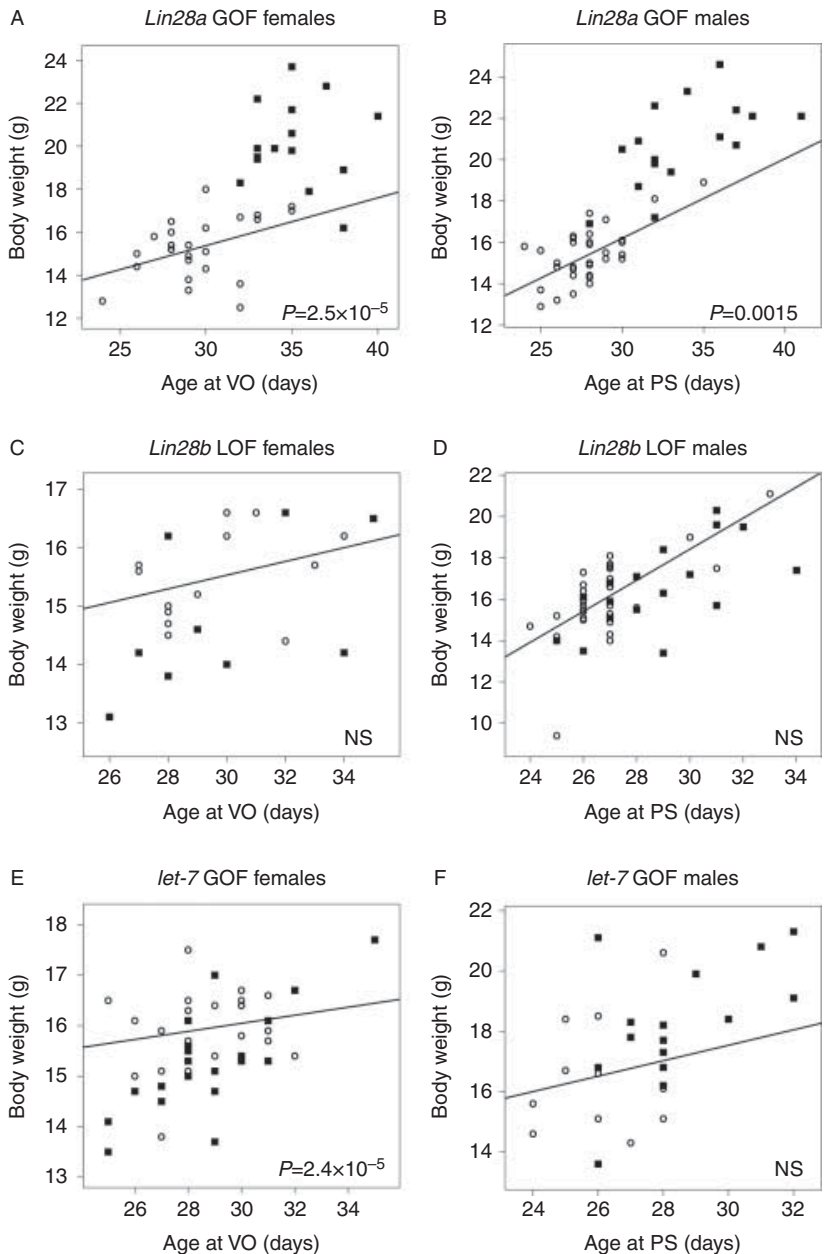

Figure 3

Weight and age at puberty for each control (open circles) and transgenic (black boxes) mouse. The line represents linear regression of weight and age at VO/PS for controls. Significant differences in the relationship of age and weight at puberty between controls and transgenic mice were detected in both male and female Lin28a GOF mice and among let-7 GOF females.

Published by Bioscientifica Ltd 

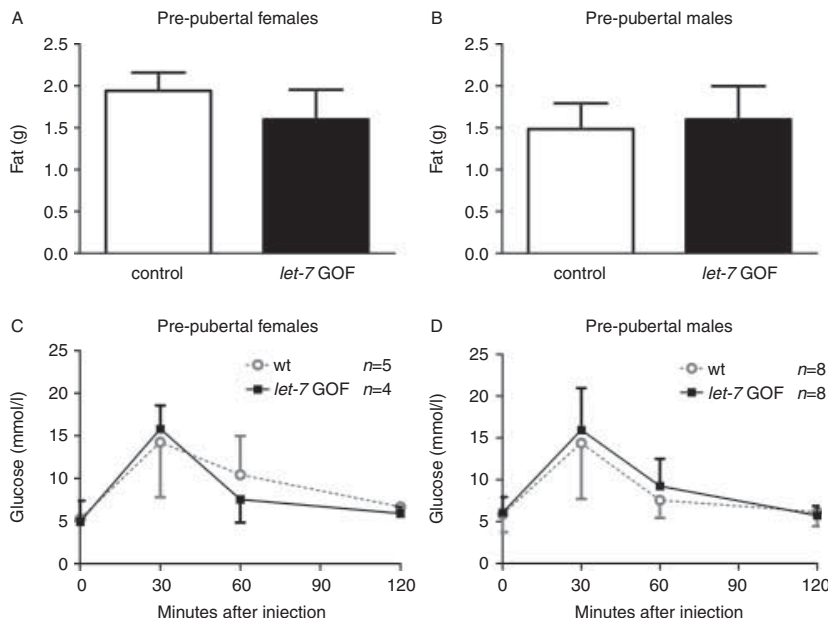

Figure 4

Body fat content and glucose metabolism are similar in let-7 GOF mice and controls. (A and B) Body fat in 22-day-old let-7 GOF and littermate control mice, $n=4-8$; similar results were obtained for percent body fat (data not shown). (C and D) IP-GTT in 21-day-old let-7 GOF and littermate control mice, $n=4-8$. Error bars represent S.D. Data were analyzed with the student's $t$-test, assuming unequal variances. No data points reached $P<0.05$.

therefore we assessed glucose metabolism in pre-pubertal let-7 GOF mice by an IP-GTT. At this young age, neither females nor males displayed abnormal glucose metabolism compared with controls (Fig. 4C and D). These data indicate that the decreased percent body fat and impaired glucose metabolism observed in adult let-7 GOF mice (Frost \& Olson 2011, Zhu et al. 2011) likely develop after puberty and are not a cause of the delayed puberty we observed.

\section{let-7 levels in Lin28b LOF and let-7 GOF mice}

Others have shown that overexpression of let-7 in the central nervous system leads to smaller body size (Frost \& Olson 2011), and we hypothesized that the observed sex differences in growth and puberty in the Lin28b LOF and let-7 GOF strains could derive from sex-specific effects on hypothalamic let-7 expression. To test this hypothesis, let-7 levels were assessed in the hypothalamus at the average age of VO or PS in the controls (see Fig. 2). In the Lin $28 b$ LOF strain, levels of let-7a and let-7 $g$ were evaluated as they have been shown to display expression levels representative of the whole let-7 family (Newman et al. 2008, Shinoda et al. 2013b). In the let-7 GOF strain, only let-7g was evaluated as this family member was the one being expressed by the transgene. No let-7 upregulation was detected in the hypothalamus (Fig. 5A and B) in either the $\operatorname{Lin} 28 b$ LOF or the let-7 GOF strain.
Because previous studies have demonstrated that Lin28b and let-7 can regulate growth peripherally (Frost \& Olson 2011, Shinoda et al. 2013b), we also investigated if the sex differences in puberty and body weight could derive from sexually dimorphic peripheral let-7 expression. let-7 levels were assessed in pituitary and gonads (as part of the HPG axis) and liver (as a non-HPG tissue) in Lin28b LOF mice. No differential regulation of let-7a or let-7g was detected in any tissue among $\operatorname{Lin} 28 \mathrm{~b}$ LOF female and male mice (Fig. 6A and B). We also assessed whether the lack of sufficient changes in peripheral let-7 expression in female mice might explain why these mice were less affected than the males. However, contrary to this hypothesis, overexpression was either similar in both sexes or greater in females than in males (Fig. 6C and D).

\section{Discussion}

Differences exist between boys and girls and men and women in many growth-related traits such as height, body mass index, waist to hip ratio, and the timing of puberty. The basis for these differences is not fully understood, but understanding the differences is important because they are linked to cardiovascular and other health outcomes (Weir et al. 1998, Golub et al. 2008, Lakshman et al. 2009, Joinson et al. 2011, Seselj et al. 2012, Widen et al. 2012, Ritte et al. 2013, Day et al. 2015). Certainly sex steroids play a role in this sex specificity and so do sex chromosomes as is evidenced by the height in women with complete androgen insensitivity and Turner syndrome. GWAS present a new opportunity to further our understanding of sex specificity among complex traits
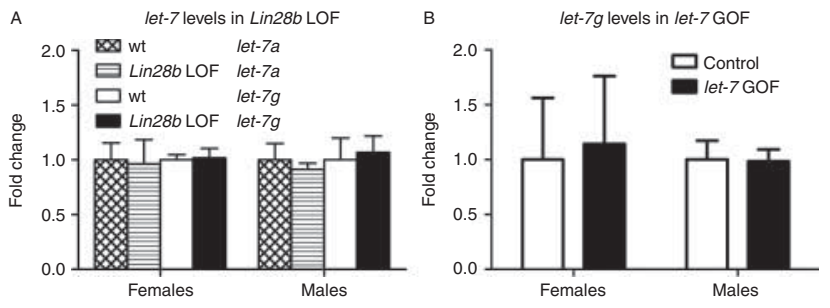

\section{Figure 5}

Hypothalamic let-7 expression levels were unaltered in Lin28b LOF and in let-7 GOF mice compared with controls. (A) let-7a and let-7g levels in hypothalamus on the mean day of PS (postnatal day 27) or VO (postnatal day 30) among control Lin28b LOF mice, $n=3-4$. (B) let-7g levels in hypothalamus on the mean day of PS (postnatal day 26) or VO (postnatal day 29) among controls and let-7 GOF mice, $n=3-4$. Error bars represent s.D. Expression data were analyzed using the student's $t$-test. No data points reached $P<0.05$.

Published by Bioscientifica Ltd. 

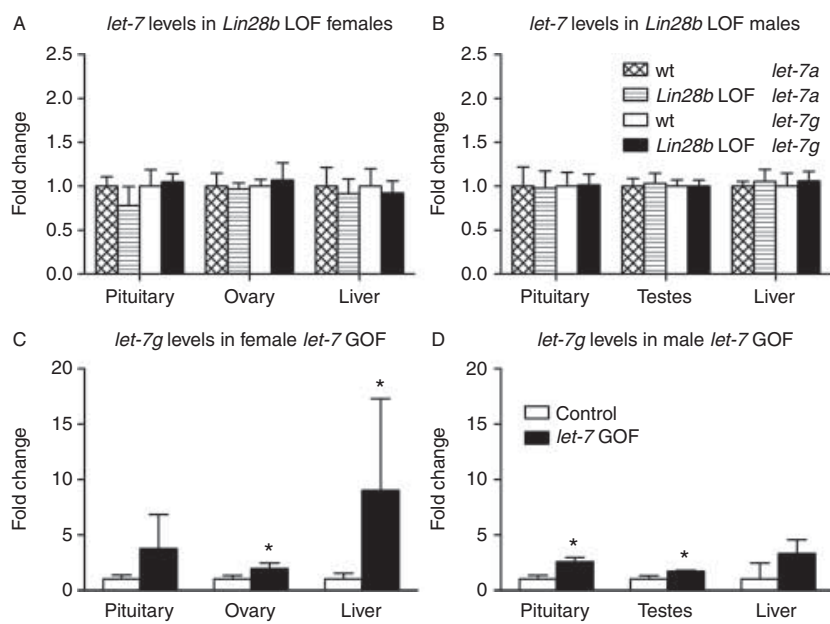

\section{Figure 6}

Peripheral let-7 expression levels were unaltered in Lin28b LOF mice, but upregulated in in let-7 GOF mice. (A and B) let-7a and let-7g levels in pituitary, gonads, and liver in Lin28b LOF mice on the mean day of VO (postnatal day 30) or PS (postnatal day 27) among control mice, $n=3-4$. ( $C$ and $D$ ) let-7g levels in pituitary, gonads, and liver on the mean day of Vo (postnatal day 29) or PS (postnatal day 26) in let-7 GOF mice, $n=3-4$. Error bars represent s.D. Expression data were analyzed using the student's $t$-test. ${ }^{*} P<0.05$.

(Magi et al. 2010, Gilks et al. 2014). Although the vast majority of the identified loci are likely not to exert sex-specific effects, recent studies have identified sexspecific (Winkler et al. 2015) and sex-chromosome dependent loci (Lunetta et al. 2015) that affect body size and pubertal timing. Moreover, even in the absence of genetic variants with sex specific effects, the study of the genes and pathways identified by GWAS provides an opportunity to uncover new factors that contribute to male-female differences in traits such as growth and the timing of puberty since, for example, these genes and pathways may be modulated by differential sex-steroid exposures or epigenetic mechanisms.

Sex-specific effects of the Lin28a/Lin28b/let-7 axis have already been identified in growth patterns in mice and humans (Lettre et al. 2008, Widen et al. 2010, Ong et al. 2011, Leinonen et al. 2012, Shinoda et al. 2013b, Cousminer et al. 2014). By verifying previously published sex differences in the regulation of body weight in a second animal facility and expanding these observations to include sex-specific effects on pubertal timing, we provide further evidence that the Lin28a/Lin28b/let-7 axis can exert sex-specific effects in mice. The mechanism(s) for these sex-specific effects remains unclear, but recent evidence point towards neonatal sex hormone exposure as one regulator of the Lin28a, Lin28b, and let-7 pathway
(Sangiao-Alvarellos et al. 2013, Sangiao-Alvarellos et al. 2015). Our findings highlight the importance of understanding the sex-specific effects of this complex pathway and its contribution to differences in growth and puberty seen in boys and girls.

Following the association of LIN28B with AAM (He et al. 2009, Ong et al. 2009, Perry et al. 2009, Sulem et al. 2009, Elks et al. 2010), researchers investigated whether variants in $L I N 28 B$ underlie central precocious puberty in girls (Silveira-Neto et al. 2012) or constitutional delay of growth and puberty in boys (Tommiska et al. 2010). The results indicate that such variation is not a common cause of these extreme phenotypes and suggest that the primary role of $L I N 28 B$ may be in regulating the timing of puberty within the general population. In contrast to other studies using more severely affected animals (Good et al. 1997, Corradi et al. 2003, Seminara et al. 2003, Pask et al. 2005, Brill \& Moenter 2009, DeBoer et al. 2010, Deboer \& Li 2011, Elias \& Purohit 2013), all three strains of our mice were healthy and fertile and were thus a good model for studying genes that affect timing of puberty in the general population. Similarly, the two-day delay detected in our transgenic male mice is of comparable magnitude to studies of litter-size and diet manipulations in male mice (DeBoer et al. 2010, Smith \& Spencer 2012, SanchezGarrido et al. 2013). In contrast, when the HPG axis is severely perturbed with impaired fertility as a result, PS and VO can be delayed 7-11 and 9 days, respectively (Novaira et al. 2014). The five-day delay in puberty seen among our Lin28a GOF mice may indicate that Lin28a plays a larger role than $L i n 28 b$ in regulating the reproductive endocrine axis in mice (Zhu et al. 2010).

Although the physiology of puberty in mice and humans is not identical, decades of experiments have demonstrated that the mouse is an informative model in the study of reproductive endocrinology. Mice, like humans, display sex-differences in the timing of puberty, although in mice the direction of this sex difference can be strain-specific (Krewson et al. 2004, Nathan et al. 2006, Tyl et al. 2008a,b, Divall et al. 2010). While the effects of SNPs and knockouts may also be species-specific, our data underscore that the Lin28a/Lin28b/let-7 pathway is a key regulator of growth and pubertal timing and suggest that it may be responsible for some of the sex-specific differences seen in these traits among humans.

Lin28a and Lin28b are paralogues that appear to have overlapping as well as separate functions. Here we show that some aspects of Lin28a GOF are mirrored by Lin28b LOF mice (Lin28a GOF mice are larger and Lin28b LOF mice are smaller than controls). Other aspects differ, such

Published by Bioscientifica Ltd. 
as presence of sex-specificity and the direction of changes in pubertal timing. The age/weight relationship at puberty is also perturbed in the Lin28a GOF mice when compared with controls, whereas the relationship is unaltered in Lin28b LOF mice. Functions in humans may differ too. GWAS have not demonstrated that variants in LIN28A associate with AAM in humans, but this could stem from this gene having tolerated less sequence variation during evolution, thus lacking variants that could associate with AAM. Consistent with this idea is the observation that Lin28a LOF mice either die young or display reduced fertility as adults (Zhu et al. 2010, Shinoda et al. 2013a). In addition, a recent study by Sangiao-Alvarellos demonstrates that expression levels of $\operatorname{Lin} 28 a$ and $\operatorname{Lin} 28 b$ are regulated in opposite directions in the testes after hypophysectomy, supporting our findings that Lin28a and Lin28b act in different ways in the HPG axis (Sangiao-Alvarellos et al. 2015). That Lin28a and Lin28b may have separate functions is further supported by cancer studies that often identify either Lin $28 a$ or Lin28b as a regulator of cell fates (Zhou et al. 2013) and by different expression patterns that have been observed in mouse (Grieco et al. 2013) and rat tissues (Sangiao-Alvarellos et al. 2013). On a cellular level, Lin28a and Lin28b operate in separate compartments of the cell (Piskounova et al. 2011).

Lin28a and Lin28b exert most of their effects through inhibition of let-7 levels but also have let-7 independent functions (Polesskaya et al. 2007, Xu \& Huang 2009, Xu et al. 2009, Balzer et al. 2010, Qiu et al. 2010, Peng et al. 2011, Wilbert et al. 2012). For example, it has been shown that Lin28a can bind mRNA directly and stimulate translation (Polesskaya et al. 2007, Xu et al. 2009, Xu \& Huang 2009, Qiu et al. 2010) via motifs that are found in many genes (Peng et al. 2011, Wilbert et al. 2012). Our data are consistent with the concept of both let-7 dependent and independent functions of Lin28a/Lin28b. For example, let-7 GOF mice show similar weight and puberty phenotypes as the Lin28b LOF mice, including sex specificity, and the let-7 GOF mice display body weight phenotypes in the opposite direction of Lin28a GOF mice. On the other hand, the Lin28a GOF mice display no sex specificity, and in the Lin $28 b$ LOF males, lighter body weights are apparent at younger ages than in the let-7 GOF strain. In addition, the relationship between age/weight at puberty is not perturbed in the Lin28b LOF mice, but female let-7 GOF mice display an altered relationship compared with controls, suggesting that some effects of let-7 may be independent of Lin28a and Lin28b.

Because Lin28b can downregulate let-7, we expected elevated let-7 levels in Lin28b LOF mice. However, as reported by several others using animals with modulated Lin28a or Lin28b expression, there were no apparent differences among let-7 levels in the tissues examined in Lin28b LOF mice (Zhu et al. 2010, Faas et al. 2013, Shinoda et al. 2013b, Ouchi et al. 2014). It is possible that, as shown in recent studies in Xenopus and C. elegans, Lin28a and Lin28b may modulate let-7 levels only during specific developmental stages (Vadla et al. 2012, Faas et al. 2013), and we may not have assessed the specific timepoint(s) at which this modulation occurs. This possibility is further supported by the observation that the sex-specificity in the body weight reduction is detected when the let-7 GOF is induced from birth, but not when induced from weaning (Zhu et al. 2011).

The concept of age/developmental stage-specific regulation is supported by the finding that changes in Lin28b expression in the fetus have greater effects on growth than changes later in life (Shinoda et al. 2013b). Thus, elevated let-7 levels during a short, but critical, window during development may be sufficient to induce phenotypic effects later in life. In WT animals, gene expression of Lin28a and Lin28b decrease and let-7 levels increase from birth to adulthood, but the gene expression levels are relatively stable between juvenile and pubertal stages, raising the possibility that the puberty-modulating phase may occur earlier during development (Grieco et al. 2013, Sangiao-Alvarellos et al. 2013). Further studies of the Lin28a/Lin28b/let-7 axis at different times during development are needed to inform us of critical windows during which this axis may program future phenotypes. A timecourse of Lin28a/Lin28b/let-7 expression throughout postnatal development and across the pubertal transition in mice with perturbed Lin28a/Lin28b/let-7 pathways might be particularly informative.

Despite the limitations related to critical windows, we examined levels of let-7 gene expression in several tissues to explore the origin of the male-specific responses to let-7 GOF. Although males exhibited more and stronger phenotypes than females, overall males displayed a lower degree of let-7 overexpression than females, raising the possibility that regulation of growth and puberty may be more let-7 sensitive in males than in females. Interestingly, the degree of $l e t-7 g$ upregulation in the let-7 GOF mice varied among tissues, and was absent in the CNS as has been reported by others (Frost \& Olson 2011, Zhu et al. 2011), suggesting that either we assessed expression at a time point at which let-7 is resistant to upregulation, or that weight and puberty phenotypes may not be mediated by let-7 action in the hypothalamus. Indeed, others have previously demonstrated that phenotypes detected in

Published by Bioscientifica Ltd. 
CNS-restricted let-7 GOF mice are not always detected in global let-7 GOF mice, and vice versa, perhaps suggesting a combination of central and peripheral effects (Frost \& Olson 2011). Further studies using tissue-specific GOF or LOF of let-7 miRNAs are needed to determine the precise site(s) of regulation of growth and puberty by let- 7 .

In summary, the data from our LOF and GOF strains demonstrate complex and sex-specific regulation of growth and puberty by Lin28a, Lin28b, and let-7. The data also point to possible critical windows and peripheral vs central regulation. This complexity consistent with human data showing that the dominant allele at rs314276 (the SNP that displays the strongest association with AAM) is associated with shorter height and heavier weight in women but not men (Ong et al. 2011). In addition, two other LIN28B SNPs that associate with AAM and adult height, rs314277 and rs7759938, contribute differentially to adult height in females and males (Widen et al. 2010). These findings in humans and our data in mice suggest that further study of the Lin28b LOF and let-7 GOF strains will provide an important opportunity to expand our understanding of how puberty and growth are modulated in males and females, including the basis of some sexspecific effects. In addition, our models have no apparent underlying illness, in keeping with humans with genetic variants in LIN28B, indicating that these strains also provide an opportunity to study a pathway identified through GWAS that regulates the onset of puberty within the 'normal' population.

\section{Declaration of interests}

The authors declare that there is no conflict of interest that could be perceived as prejudicing the impartiality of the research reported.

\section{Funding}

This work was funded by the Canadian Institutes for Health Research and by Department of Paediatrics, The Hospital for Sick Children.

\section{Author contribution statement}

C C carried out experiments, performed data analysis, and wrote the manuscript. D L C, C C, C C , and C B carried out experiments. G S, H Z, G Q D, $A G$, and $M R P$ conceived the study, assisted in interpretation of results, and edited the manuscript. A G performed linear regression analysis.

\section{Acknowledgements}

The authors wish to acknowledge the contribution from the Clinical Phenotyping Core at The Toronto Centre for Phenogenomics (TCP) for their assistance with DEXA scans and the TCP Transgenic Core for their assistance with rederivation.

\section{References}

Ambros V \& Horvitz HR 1984 Heterochronic mutants of the nematode Caenorhabditis elegans. Science 226 409-416. (doi:10.1126/science. 6494891)

Baker H, Joh TH, Ruggiero DA \& Reis DJ 1983 Variations in number of dopamine neurons and tyrosine hydroxylase activity in hypothalamus of two mouse strains. Journal of Neuroscience 3 832-843.

Balzer E, Heine C, Jiang Q, Lee VM \& Moss EG 2010 LIN28 alters cell fate succession and acts independently of the let-7 microRNA during neurogliogenesis in vitro. Development 137 891-900. (doi:10.1242/ dev.042895)

Beard C, Hochedlinger K, Plath K, Wutz A \& Jaenisch R 2006 Efficient method to generate single-copy transgenic mice by site-specific integration in embryonic stem cells. Genesis 44 23-28. (doi:10.1002/gene.20180)

Brill DS \& Moenter SM 2009 Androgen receptor antagonism and an insulin sensitizer block the advancement of vaginal opening by high-fat diet in mice. Biology of Reproduction 81 1093-1098. (doi:10.1095/biolreprod. 109.079301)

Carel JC \& Leger J 2008 Clinical practice. Precocious puberty. New England Journal of Medicine 358 2366-2377. (doi:10.1056/NEJMcp0800459)

Caron E, Ciofi P, Prevot V \& Bouret SG 2012 Alteration in neonatal nutrition causes perturbations in hypothalamic neural circuits controlling reproductive function. Journal of Neuroscience 32 11486-11494. (doi:10.1523/JNEUROSCI.6074-11.2012)

Chehab FF, Mounzih K, Lu R \& Lim ME 1997 Early onset of reproductive function in normal female mice treated with leptin. Science 275 88-90. (doi:10.1126/science.275.5296.88)

Corradi A, Croci L, Broccoli V, Zecchini S, Previtali S, Wurst W, Amadio S, Maggi R, Quattrini A \& Consalez GG 2003 Hypogonadotropic hypogonadism and peripheral neuropathy in Ebf2-null mice. Development 130 401-410. (doi:10.1242/dev.00215)

Cousminer DL, Berry DJ, Timpson NJ, Ang W, Thiering E, Byrne EM, Taal HR, Huikari V, Bradfield JP, Kerkhof M et al. 2013 Genome-wide association and longitudinal analyses reveal genetic \%loci linking pubertal height growth, pubertal timing and childhood adiposity. Human Molecular Genetics 22 2735-2747. (doi:10.1093/ $\mathrm{hmg} / \mathrm{ddt104)}$

Cousminer DL, Stergiakouli E, Berry DJ, Ang W, Groen-Blokhuis MM, Korner A, Siitonen N, Ntalla I, Marinelli M, Perry JR et al. 2014 Genomewide association study of sexual maturation in males and females highlights a role for body mass and menarche loci in male puberty. Human Molecular Genetics 23 4452-4464. (doi:10.1093/hmg/ddu150)

Danilovich N, Wernsing D, Coschigano KT, Kopchick JJ \& Bartke A 1999 Deficits in female reproductive function in GH-R-KO mice; role of IGF-I. Endocrinology 140 2637-2640. (doi:10.1210/endo.140.6.6992)

Day FR, Elks CE, Murray A, Ong KK \& Perry JR 2015 Puberty timing associated with diabetes, cardiovascular disease and also diverse health outcomes in men and women: the UK Biobank study. Scientific Reports 5 11208. (doi:10.1038/srep11208)

Deboer MD \& Li Y 2011 Puberty is delayed in male mice with dextran sodium sulfate colitis out of proportion to changes in food intake, body weight, and serum levels of leptin. Pediatric Research 69 34-39. (doi:10.1203/PDR.0b013e3181ffee6c)

DeBoer MD, Li Y \& Cohn S 2010 Colitis causes delay in puberty in female mice out of proportion to changes in leptin and corticosterone. Journal of Gastroenterology 45 277-284. (doi:10.1007/ s00535-009-0192-x)

Dicken CL, Israel DD, Davis JB, Sun Y, Shu J, Hardin J \& Neal-Perry G 2012 Peripubertal vitamin $\mathrm{D}(3)$ deficiency delays puberty and disrupts the estrous cycle in adult female mice. Biology of Reproduction $\mathbf{8 7} 51$. (doi:10.1095/biolreprod.111.096511)

Divall SA, Williams TR, Carver SE, Koch L, Bruning JC, Kahn CR, Wondisford F, Radovick S \& Wolfe A 2010 Divergent roles of growth 
factors in the GnRH regulation of puberty in mice. Journal of Clinical Investigation 120 2900-2909. (doi:10.1172/JCI41069)

Elias CF \& Purohit D 2013 Leptin signaling and circuits in puberty and fertility. Cellular and Molecular Life Sciences 70 841-862. (doi:10.1007/ s00018-012-1095-1)

Elks CE, Perry JR, Sulem P, Chasman DI, Franceschini N, He C, Lunetta KL, Visser JA, Byrne EM, Cousminer DL et al. 2010 Thirty new loci for age at menarche identified by a meta-analysis of genome-wide association studies. Nature Genetics 42 1077-1085. (doi:10.1038/ng.714)

Faas L, Warrander FC, Maguire R, Ramsbottom SA, Quinn D, Genever P \& Isaacs HV 2013 Lin28 proteins are required for germ layer specification in Xenopus. Development 140 976-986. (doi:10.1242/dev.089797)

Fernandez-Fernandez R, Martini AC, Navarro VM, Castellano JM, Dieguez C, Aguilar E, Pinilla L \& Tena-Sempere M 2006 Novel signals for the integration of energy balance and reproduction. Molecular and Cellular Endocrinology 254-255 127-132. (doi:10.1016/j.mce.2006. 04.026)

Frost RJ \& Olson EN 2011 Control of glucose homeostasis and insulin sensitivity by the Let-7 family of microRNAs. PNAS $\mathbf{1 0 8} 21075-21080$. (doi:10.1073/pnas.1118922109)

Gaytan F, Sangiao-Alvarellos S, Manfredi-Lozano M, Garcia-Galiano D, Ruiz-Pino F, Romero-Ruiz A, Leon S, Morales C, Cordido F, Pinilla L et al. 2013 Distinct expression patterns predict differential roles of the miRNA-binding proteins. Lin28 and Lin28b, in the mouse testis: studies during postnatal development and in a model of hypogonadotropic hypogonadism. Endocrinology 154 1321-1336. (doi:10.1210/en.2012-1745)

Gilks WP, Abbott JK \& Morrow EH 2014 Sex differences in disease genetics: evidence, evolution, and detection. Trends in Genetics 30 453-463. (doi:10.1016/j.tig.2014.08.006)

Golub MS, Collman GW, Foster PM, Kimmel CA, Reiter EO, Sharpe RM, Skakkebaek NE \& Toppari J 2008 Public health implications of altered puberty timing. Pediatrics 121(Suppl 3) S218-S230. (doi:10.1542/peds. 2007-1813G)

Good DJ, Porter FD, Mahon KA, Parlow AF, Westphal H \& Kirsch IR 1997 Hypogonadism and obesity in mice with a targeted deletion of the Nhlh2 gene. Nature Genetics 15 397-401. (doi:10.1038/ng0497-397)

Grieco A, Rzeczkowska P, Alm C \& Palmert MR 2013 Investigation of peripubertal expression of Lin28a and Lin28b in C57BL/6 female mice. Molecular and Cellular Endocrinology 365 241-248. (doi:10.1016/j.mce. 2012.10.025)

He C, Kraft P, Chen C, Buring JE, Pare G, Hankinson SE, Chanock SJ, Ridker PM, Hunter DJ \& Chasman DI 2009 Genome-wide association studies identify loci associated with age at menarche and age at natural menopause. Nature Genetics 41 724-728. (doi:10.1038/ng.385)

Heo I, Joo C, Cho J, Ha M, Han J \& Kim VN 2008 Lin28 mediates the terminal uridylation of let-7 precursor MicroRNA. Molecular Cell 32 276-284. (doi:10.1016/j.molcel.2008.09.014)

Joinson C, Heron J, Lewis G, Croudace T \& Araya R 2011 Timing of menarche and depressive symptoms in adolescent girls from a UK cohort. British Journal of Psychiatry 198 17-23; Sup 1-2. (doi:10.1192/bjp.bp.110.080861)

King CE, Cuatrecasas M, Castells A, Sepulveda AR, Lee JS \& Rustgi AK 2011 LIN28B promotes colon cancer progression and metastasis. Cancer Research 71 4260-4268. (doi:10.1158/0008-5472.CAN-10-4637)

Korenbrot CC, Huhtaniemi IT \& Weiner RI 1977 Preputial separation as an external sign of pubertal development in the male rat. Biology of Reproduction 17 298-303. (doi:10.1095/biolreprod17.2.298)

Krewson TD, Supelak PJ, Hill AE, Singer JB, Lander ES, Nadeau JH \& Palmert MR 2004 Chromosomes 6 and 13 harbor genes that regulate pubertal timing in mouse chromosome substitution strains. Endocrinology 145 4447-4451. (doi:10.1210/en.2004-0543)

Lakshman R, Forouhi NG, Sharp SJ, Luben R, Bingham SA, Khaw KT, Wareham NJ \& Ong KK 2009 Early age at menarche associated with cardiovascular disease and mortality. Journal of Clinical Endocrinology and Metabolism 94 4953-4960. (doi:10.1210/jc.2009-1789)
Leinonen JT, Surakka I, Havulinna AS, Kettunen J, Luoto R, Salomaa V \& Widen E 2012 Association of LIN28B with adult adiposity-related traits in females. PLOS ONE 7 e48785. (doi:10.1371/journal.pone.0048785)

Lettre G, Jackson AU, Gieger C, Schumacher FR, Berndt SI, Sanna S, Eyheramendy S, Voight BF, Butler JL, Guiducci C et al. 2008 Identification of ten loci associated with height highlights new biological pathways in human growth. Nature Genetics 40 584-591. (doi:10.1038/ng.125)

Lunetta KL, Day FR, Sulem P, Ruth KS, Tung JY, Hinds DA, Esko T, Elks CE, Altmaier E, He C et al. 2015 Rare coding variants and X-linked loci associated with age at menarche. Nature Communications 67756. (doi:10.1038/ncomms8756)

Magi R, Lindgren CM \& Morris AP 2010 Meta-analysis of sex-specific genome-wide association studies. Genetic Epidemiology 34 846-853. (doi:10.1002/gepi.20540)

Melton C, Judson RL \& Blelloch R 2010 Opposing microRNA families regulate self-renewal in mouse embryonic stem cells. Nature $\mathbf{4 6 3}$ 621-626. (doi:10.1038/nature08725)

Molenaar JJ, Domingo-Fernandez R, Ebus ME, Lindner S, Koster J, Drabek K, Mestdagh P, van Sluis P, Valentijn LJ, van Nes J et al. 2012 LIN28B induces neuroblastoma and enhances MYCN levels via let-7 suppression. Nature Genetics 44 1199-1206. (doi:10.1038/ng.2436)

Nathan BM, Hodges CA, Supelak PJ, Burrage LC, Nadeau JH \& Palmert MR 2006 A quantitative trait locus on chromosome 6 regulates the onset of puberty in mice. Endocrinology 147 5132-5138. (doi:10.1210/en.2006-0745)

Newman MA, Thomson JM \& Hammond SM 2008 Lin-28 interaction with the Let-7 precursor loop mediates regulated microRNA processing. RNA 14 1539-1549. (doi:10.1261/rna.1155108)

Novaira HJ, Sonko ML, Hoffman G, Koo Y, Ko C, Wolfe A \& Radovick S 2014 Disrupted kisspeptin signaling in GnRH neurons leads to hypogonadotrophic hypogonadism. Molecular Endocrinology 28 225-238. (doi:10.1210/me.2013-1319)

Ong KK, Elks CE, Li S, Zhao JH, Luan J, Andersen LB, Bingham SA, Brage S, Smith GD, Ekelund U et al. 2009 Genetic variation in LIN28B is associated with the timing of puberty. Nature Genetics $\mathbf{4 1} 729-733$. (doi:10.1038/ng.382)

Ong KK, Elks CE, Wills AK, Wong A, Wareham NJ, Loos RJ, Kuh D \& Hardy R 2011 Associations between the pubertal timing-related variant in LIN28B and BMI vary across the life course. Journal of Clinical Endocrinology and Metabolism 96 E125-E129. (doi:10.1210/ jc.2010-0941)

Ouchi Y, Yamamoto J \& Iwamoto T 2014 The heterochronic genes lin-28a and lin-28b play an essential and evolutionarily conserved role in early zebrafish development. PLOS ONE 9 e88086. (doi:10.1371/journal. pone.0088086)

Palmert MR \& Dunkel L 2012 Clinical practice. Delayed puberty. New England Journal of Medicine 366 443-453. (doi:10.1056/ NEJMcp1109290)

Pask AJ, Kanasaki H, Kaiser UB, Conn PM, Janovick JA, Stockton DW, Hess DL, Justice MJ \& Behringer RR 2005 A novel mouse model of hypogonadotrophic hypogonadism: N-ethyl-N-nitrosourea-induced gonadotropin-releasing hormone receptor gene mutation. Molecular Endocrinology 19 972-981. (doi:10.1210/me.2004-0192)

Pasquinelli AE, Reinhart BJ, Slack F, Martindale MQ, Kuroda MI, Maller B, Hayward DC, Ball EE, Degnan B, Muller P et al. 2000 Conservation of the sequence and temporal expression of let-7 heterochronic regulatory RNA. Nature 408 86-89. (doi:10.1038/35040556)

Peng S, Maihle NJ \& Huang Y 2010 Pluripotency factors Lin28 and Oct4 identify a sub-population of stem cell-like cells in ovarian cancer. Oncogene 29 2153-2159. (doi:10.1038/onc.2009.500)

Peng S, Chen LL, Lei XX, Yang L, Lin H, Carmichael GG \& Huang Y 2011 Genome-wide studies reveal that Lin28 enhances the translation of genes important for growth and survival of human embryonic stem cells. Stem Cells 29 496-504. (doi:10.1002/stem.591) http://joe.endocrinology-journals.org

DOI: $10.1530 / J O E-15-0360$
(C) 2016 Society for Endocrinology Printed in Great Britain
Published by Bioscientifica Ltd 
Perry JR, Stolk L, Franceschini N, Lunetta KL, Zhai G, McArdle PF, Smith AV, Aspelund T, Bandinelli S, Boerwinkle E et al. 2009 Meta-analysis of genome-wide association data identifies two loci influencing age at menarche. Nature Genetics 41 648-650. (doi:10.1038/ng.386)

Perry JR, Day F, Elks CE, Sulem P, Thompson DJ, Ferreira T, He C, Chasman DI, Esko T, Thorleifsson G et al. 2014 Parent-of-origin-specific allelic associations among 106 genomic loci for age at menarche. Nature 514 92-97. (doi:10.1038/nature13545)

Piskounova E, Polytarchou C, Thornton JE, LaPierre RJ, Pothoulakis C, Hagan JP, Iliopoulos D \& Gregory RI 2011 Lin28A and Lin28B inhibit let-7 microRNA biogenesis by distinct mechanisms. Cell $\mathbf{1 4 7}$ 1066-1079. (doi:10.1016/j.cell.2011.10.039)

Polesskaya A, Cuvellier S, Naguibneva I, Duquet A, Moss EG \& Harel-Bellan A 2007 Lin-28 binds IGF-2 mRNA and participates in skeletal myogenesis by increasing translation efficiency. Genes and Development 21 1125-1138. (doi:10.1101/gad.415007)

Qiu C, Ma Y, Wang J, Peng S \& Huang Y 2010 Lin28-mediated posttranscriptional regulation of Oct4 expression in human embryonic stem cells. Nucleic Acids Research 38 1240-1248. (doi:10.1093/nar/ gkp1071)

Reinhart BJ, Slack FJ, Basson M, Pasquinelli AE, Bettinger JC, Rougvie AE, Horvitz HR \& Ruvkun G 2000 The 21-nucleotide let-7 RNA regulates developmental timing in Caenorhabditis elegans. Nature 403 901-906. (doi:10.1038/35002607)

Ritte R, Lukanova A, Tjonneland A, Olsen A, Overvad K, Mesrine S, Fagherazzi G, Dossus L, Teucher B, Steindorf K et al. 2013 Height, age at menarche and risk of hormone receptor-positive and -negative breast cancer: a cohort study. International Journal of Cancer 132 2619-2629. (doi:10.1002/ijc.27913)

Rybak A, Fuchs H, Smirnova L, Brandt C, Pohl EE, Nitsch R \& Wulczyn FG 2008 A feedback loop comprising lin-28 and let-7 controls pre-let-7 maturation during neural stem-cell commitment. Nature Cell Biology 10 987-993. (doi:10.1038/ncb1759)

Sakurai M, Miki Y, Masuda M, Hata S, Shibahara Y, Hirakawa H, Suzuki T \& Sasano H 2012 LIN28: a regulator of tumor-suppressing activity of let-7 microRNA in human breast cancer. Journal of Steroid Biochemistry and Molecular Biology 131 101-106. (doi:10.1016/j.jsbmb.2011.10.007)

Sanchez-Garrido MA, Castellano JM, Ruiz-Pino F, Garcia-Galiano D, Manfredi-Lozano M, Leon S, Romero-Ruiz A, Dieguez C, Pinilla L \& Tena-Sempere M 2013 Metabolic programming of puberty: sexually dimorphic responses to early nutritional challenges. Endocrinology 154 3387-3400. (doi:10.1210/en.2012-2157)

Sangiao-Alvarellos S, Manfredi-Lozano M, Ruiz-Pino F, Navarro VM, Sanchez-Garrido MA, Leon S, Dieguez C, Cordido F, Matagne V, Dissen GA et al. 2013 Changes in hypothalamic expression of the Lin28/let-7 system and related microRNAs during postnatal maturation and after experimental manipulations of puberty. Endocrinology $\mathbf{1 5 4}$ 942-955. (doi:10.1210/en.2012-2006)

Sangiao-Alvarellos S, Manfredi-Lozano M, Ruiz-Pino F, Leon S, Morales C, Cordido F, Gaytan F, Pinilla L \& Tena-Sempere M 2015 Testicular expression of the Lin28/let-7 system: Hormonal regulation and changes during postnatal maturation and after manipulations of puberty. Scientific Reports 5 15683. (doi:10.1038/srep15683)

Seminara SB, Messager S, Chatzidaki EE, Thresher RR, Acierno JS Jr, Shagoury JK, Bo-Abbas Y, Kuohung W, Schwinof KM, Hendrick AG et al. 2003 The GPR54 gene as a regulator of puberty. New England Journal of Medicine 349 1614-1627. (doi:10.1056/NEJMoa035322)

Seselj M, Nahhas RW, Sherwood RJ, Chumlea WC, Towne B \& Duren DL 2012 The influence of age at menarche on cross-sectional geometry of bone in young adulthood. Bone $\mathbf{5 1} 38-45$. (doi:10.1016/ j.bone.2012.03.030)

Shinoda G, Shyh-Chang N, de Soysa TY, Zhu H, Seligson MT, Shah SP, Abo-Sido N, Yabuuchi A, Hagan JP, Gregory RI et al. 2013a Fetal deficiency of Lin28 programs life-long aberrations in growth and glucose metabolism. Stem Cells 31 1563-1573. (doi:10.1002/stem.1423)

http://joe.endocrinology-journals.org DOI: $10.1530 / J O E-15-0360$
(C) 2016 Society for Endocrinology Printed in Great Britain
Shinoda G, De Soysa TY, Seligson MT, Yabuuchi A, Fujiwara Y, Huang PY, Hagan JP, Gregory RI, Moss EG \& Daley GQ 2013b Lin28a regulates germ cell pool size and fertility. Stem Cells 31 1001-1009. (doi:10.1002/ stem.1343)

Silveira-Neto AP, Leal LF, Emerman AB, Henderson KD, Piskounova E, Henderson BE, Gregory RI, Silveira LF, Hirschhorn JN, Nguyen TT et al. 2012 Absence of functional LIN28B mutations in a large cohort of patients with idiopathic central precocious puberty. Hormone Research in Poediatrics 78 144-150. (doi:10.1159/000342212)

Smith JT \& Spencer SJ 2012 Preweaning over- and underfeeding alters onset of puberty in the rat without affecting kisspeptin. Biology of Reproduction 145 141-148. (doi:10.1095/biolreprod.111.097758)

Styne DM, Grumbach MM. 2012. Puberty: Ontogeny, Neuroendocrinology, Physiology, and Disorders. In Williams Textbook of Endocrinology, pp 1055-1201: Saunders Elsevier.

Sulem P, Gudbjartsson DF, Rafnar T, Holm H, Olafsdottir EJ, Olafsdottir GH, Jonsson T, Alexandersen P, Feenstra B, Boyd HA et al. 2009 Genome-wide association study identifies sequence variants on 6q21 associated with age at menarche. Nature Genetics 41 734-738. (doi:10.1038/ng.383)

Sun R, Zhao K, Shen R, Cai L, Yang X, Kuang Y, Mao J, Huang F, Wang Z \& Fei J 2012 Inducible and reversible regulation of endogenous gene in mouse. Nucleic Acids Research 40 e166. (doi:10.1093/nar/gks738)

Takashima-Sasaki K, Komiyama M, Adachi T, Sakurai K, Kato H, Iguchi T \& Mori C 2006 Effect of exposure to high isoflavone-containing diets on prenatal and postnatal offspring mice. Bioscience, Biotechnology, and Biochemistry 70 2874-2882. (doi:10.1271/bbb.60278)

Thomson JM, Newman M, Parker JS, Morin-Kensicki EM, Wright T \& Hammond SM 2006 Extensive post-transcriptional regulation of microRNAs and its implications for cancer. Genes and Development 20 2202-2207. (doi:10.1101/gad.1444406)

Tommiska J, Wehkalampi K, Vaaralahti K, Laitinen EM, Raivio T \& Dunkel L 2010 LIN28B in constitutional delay of growth and puberty. Journal of Clinical Endocrinology and Metabolism 95 3063-3066. (doi:10.1210/jc.2009-2344)

True C, Nasrin Alam S, Cox K, Chan YM \& Seminara SB 2015 Neurokinin B is critical for normal timing of sexual maturation but dispensable for adult reproductive function in female mice. Endocrinology $\mathbf{1 5 6}$ 1386-1397. (doi:10.1210/en.2014-1862)

Tyl RW, Myers CB, Marr MC, Castillo NP, Veselica MM, Joiner RL, Dimond SS, van Miller JP, Stropp GD, Waechter JM Jr et al. 2008a One-generation reproductive toxicity study of dietary 17beta-estradiol (E2; CAS No. 50-28-2) in CD-1 (Swiss) mice. Reproductive Toxicology 25 144-160. (doi:10.1016/j.reprotox.2007.11.012)

Tyl RW, Myers CB, Marr MC, Sloan CS, Castillo NP, Veselica MM, Seely JC, Dimond SS, van Miller JP, Shiotsuka RN et al. $2008 b$ Two-generation reproductive toxicity study of dietary bisphenol A in CD-1 (Swiss) mice. Toxicological Sciences 104 362-384. (doi:10.1093/toxsci/kfn084)

Vadla B, Kemper K, Alaimo J, Heine C \& Moss EG 2012 Lin-28 controls the succession of cell fate choices via two distinct activities. PLoS Genetics $\mathbf{8}$ e1002588. (doi:10.1371/journal.pgen.1002588)

Viswanathan SR, Daley GQ \& Gregory RI 2008 Selective blockade of microRNA processing by Lin28. Science 320 97-100. (doi:10.1126/ science.1154040)

Walvoord EC 2010 The timing of puberty: is it changing? Does it matter? Journal of Adolescent Health 47 433-439. (doi:10.1016/j.jadohealth. 2010.05.018)

Weir HK, Kreiger N \& Marrett LD 1998 Age at puberty and risk of testicular germ cell cancer (Ontario, Canada). Cancer Causes \& Control 9 253-258. (doi:10.1023/A:1008864902104)

Widen E, Ripatti S, Cousminer DL, Surakka I, Lappalainen T, Jarvelin MR, Eriksson JG, Raitakari O, Salomaa V, Sovio U et al. 2010 Distinct variants at LIN28B influence growth in height from birth to adulthood. American Journal of Human Genetics 86 773-782. (doi:10.1016/j.ajhg. 2010.03.010) 
Widen E, Silventoinen K, Sovio U, Ripatti S, Cousminer DL, Hartikainen AL, Laitinen J, Pouta A, Kaprio J, Jarvelin MR et al. 2012 Pubertal timing and growth influences cardiometabolic risk factors in adult males and females. Diabetes Care 35 850-856. (doi:10.2337/ dc11-1365)

Wilbert ML, Huelga SC, Kapeli K, Stark TJ, Liang TY, Chen SX, Yan BY, Nathanson JL, Hutt KR, Lovci MT et al. 2012 LIN28 binds messenger RNAs at GGAGA motifs and regulates splicing factor abundance. Molecular Cell 48 195-206. (doi:10.1016/j.molcel.2012.08.004)

Winkler TW, Justice AE, Graff M, Barata L, Feitosa MF, Chu S, Czajkowski J, Esko T, Fall T, Kilpelainen TO et al. 2015 The influence of age and sex on genetic associations with adult body size and shape: a large-scale genome-wide interaction study. PLoS Genetics 11 e1005378. (doi:10.1371/journal.pgen.1005378)

Xu B \& Huang Y 2009 Histone H2a mRNA interacts with Lin28 and contains a Lin28-dependent posttranscriptional regulatory element. Nucleic Acids Research 37 4256-4263. (doi:10.1093/nar/gkp372)

Xu B, Zhang K \& Huang Y 2009 Lin28 modulates cell growth and associates with a subset of cell cycle regulator mRNAs in mouse embryonic stem cells. RNA 15 357-361. (doi:10.1261/rna.1368009)
Yu J, Vodyanik MA, Smuga-Otto K, Antosiewicz-Bourget J, Frane JL, Tian S, Nie J, Jonsdottir GA, Ruotti V, Stewart R et al. 2007 Induced pluripotent stem cell lines derived from human somatic cells. Science $\mathbf{3 1 8}$ 1917-1920. (doi:10.1126/science.1151526)

Yuan J, Nguyen CK, Liu X, Kanellopoulou C \& Muljo SA 2012 Lin28b reprograms adult bone marrow hematopoietic progenitors to mediate fetal-like lymphopoiesis. Science 335 1195-1200. (doi:10.1126/science. 1216557)

Zhou J, Ng SB \& Chng WJ 2013 LIN28/LIN28B: an emerging oncogenic driver in cancer stem cells. International Journal of Biochemistry \& Cell Biology 45 973-978. (doi:10.1016/j.biocel.2013.02.006)

Zhu H, Shah S, Shyh-Chang N, Shinoda G, Einhorn WS, Viswanathan SR, Takeuchi A, Grasemann C, Rinn JL, Lopez MF et al. 2010 Lin28a transgenic mice manifest size and puberty phenotypes identified in human genetic association studies. Nature Genetics 42 626-630. (doi:10.1038/ng.593)

Zhu H, Shyh-Chang N, Segre AV, Shinoda G, Shah SP, Einhorn WS, Takeuchi A, Engreitz JM, Hagan JP, Kharas MG et al. 2011 The Lin28/ let-7 axis regulates glucose metabolism. Cell 147 81-94. (doi:10.1016/ j.cell.2011.08.033)

Received in final form 25 November 2015

Accepted 22 December 2015

Accepted Preprint published online 23 December 2015
() 2016 Society for Endocrinology Printed in Great Britain
Published by Bioscientifica Ltd. 